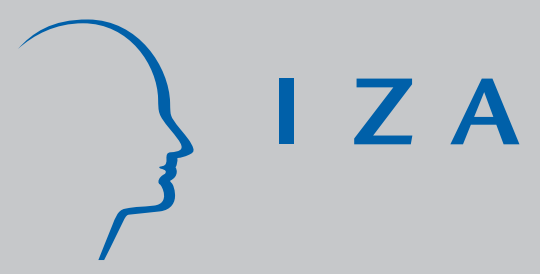

IZADP No. 3018

The Changing Face of Chinese Immigrants in Canada

Shibao Guo

Don J. DeVoretz

August 2007 


\title{
The Changing Face of Chinese Immigrants in Canada
}

\author{
Shibao Guo \\ University of Calgary
}

Don J. DeVoretz

Simon Fraser University

and IZA

\section{Discussion Paper No. 3018 \\ August 2007}

\author{
IZA \\ P.O. Box 7240 \\ 53072 Bonn \\ Germany \\ Phone: +49-228-3894-0 \\ Fax: +49-228-3894-180 \\ E-mail: iza@iza.org
}

\begin{abstract}
Any opinions expressed here are those of the author(s) and not those of the institute. Research disseminated by IZA may include views on policy, but the institute itself takes no institutional policy positions.

The Institute for the Study of Labor (IZA) in Bonn is a local and virtual international research center and a place of communication between science, politics and business. IZA is an independent nonprofit company supported by Deutsche Post World Net. The center is associated with the University of Bonn and offers a stimulating research environment through its research networks, research support, and visitors and doctoral programs. IZA engages in (i) original and internationally competitive research in all fields of labor economics, (ii) development of policy concepts, and (iii) dissemination of research results and concepts to the interested public.
\end{abstract}

IZA Discussion Papers often represent preliminary work and are circulated to encourage discussion. Citation of such a paper should account for its provisional character. A revised version may be available directly from the author. 
IZA Discussion Paper No. 3018

August 2007

\section{ABSTRACT}

\section{The Changing Face of Chinese Immigrants in Canada}

This paper analyzes the changing characteristics of Chinese immigrants to Canada between 1980 and 2001. It reveals that recent Chinese immigrants to Canada constitute a substantially different group from those of former years. They are no longer a homogeneous group from the rural areas of Guangdong Province of Mainland China, but in fact citizens of 132 countries, speaking 100 different languages and dialects. This study also reveals significant differences among Chinese subgroups. Immigrants from Hong Kong and Taiwan shared more commonalities than with those from Mainland China. Given Canada's time dependent immigration selection procedures, these differences are rationalized on the basis of a proposed single and double selection theory.

JEL Classification: J15, J60, J61

Keywords: Chinese immigration, integration, triangle theory

Corresponding author:

Don J. DeVoretz

RIIM

Simon Fraser University

Burnaby, BC V5A 156

Canada

E-mail: devoretz@sfu.ca 


\section{Introduction $^{1}$}

The 2001 Census of Canada reveals that Canada's population is becoming increasingly diverse. It reports that as of May 15, 2001, 18.4\% of Canada's total population was born outside the country, and that $13.4 \%$ identified themselves as visible minorities. The 2001 census also reports that the Chinese are now the largest visible minority group in Canada, reaching a total of 1,029,400 in 2001, up from 860,100 in 1996 (Statistics Canada, 2003). Given the magnitude of recent Chinese immigration, this study will reveal the heterogeneity of recent Chinese immigrants. It shows that Chinese immigrants are heterogeneous, contrary to the popular myth that the Chinese are homogeneous coming from a singular origin and cultural background. It will further examine the background from which Chinese immigrants came and the similarities and differences in the subgroups. We argue that this heterogeneity is a by product of Canada's immigration policy. Next the study analyzes how Canada's time dependent immigration policies led to diverse human capital characteristics in successive Chinese immigrant populations which in turn led to complex economic outcomes. We argue that the exact economic outcomes of the post-1980 wave of Chinese immigrants depend on their year of arrival, country of origin and time in Canada. It is hoped by achieving these two purposes, the analysis will provide a better understanding of recent Chinese immigrants to Canada and serve as a guide for policy-makers.

The paper is organized into five parts: a theoretical paradigm, contextual information, data analysis, a description of Chinese economic performance, and conclusions.

\section{Theory of Episodic Immigrant Flows}

Immigrants arrive in Canada under a well defined system whose entry criteria are time dependent and the Chinese are no exception to this rule. When immigration flows start from scratch in any one country such as China in the mid-1990's the only immigrant entry gate available to enter Canada is the independent immigrant class since no prior relatives exist to sponsor them. ${ }^{2}$ Given this sequence of events inherent in Canada's selection system and human capital theory it is possible to predict both the socio-demographic characteristics of these newly arrived immigrants and their initial economic outcomes. Hong Kong, Taiwan and Mainland China all had an episodic nature to their immigrant outflows. Thus, in the first instance any new flows from these areas must meet the entry criteria on their date of arrival as outlined by Canada’s “points grid” (see Table 1).

\footnotetext{
${ }^{1}$ An early version of this paper appeared in the Journal of International Migration and Integration, 7(3), 275-300.

${ }^{2}$ Refugees may enter in any sequence but China does not produce many refugees.
} 
Table 1: Selection Grid 1967-2002

\begin{tabular}{|l|c|c|c|c|c|c|c|c|}
\hline Factor/Year & $\mathbf{1 9 6 7}$ & $\mathbf{1 9 7 4}$ & $\mathbf{1 9 7 8}$ & $\mathbf{1 9 8 6}$ & $\mathbf{1 9 9 3}$ & $\mathbf{1 9 9 6}$ & $\mathbf{1 9 9 7}$ & $\mathbf{2 0 0 2}$ \\
\hline Education & 20 & 20 & 12 & 12 & 14 & 21 & 16 & 25 \\
\hline Experience & & & 8 & 8 & 8 & 9 & 8 & 21 \\
\hline Specific Vocational Preparation & 10 & 10 & 15 & 15 & 16 & & 18 & \\
\hline Occupational Demand & 15 & 15 & 10 & 10 & 10 & & 10 & \\
\hline Labour Market Balance & & & & & & 10 & & \\
\hline Age & 10 & 10 & 10 & 10 & 10 & 13 & 10 & 10 \\
\hline Arranged Employment or Designated Occ. & 10 & 10 & 10 & 10 & 10 & 4 & 10 & 10 \\
\hline Language & 10 & 10 & 15 & 15 & 14 & 21 & 15 & 24 \\
\hline Personal Suitability & 15 & 15 & 10 & 10 & 10 & 17 & 10 & 10 \\
\hline Levels & & & 10 & 10 & 8 & & & \\
\hline Demographic & & & & & & & 8 & \\
\hline Relative & $0 / 3 / 5+$ & $0 / 3 / 5$ & & & & 5 & 5 & \\
\hline Destination & 5 & 5 & & & & & & \\
\hline Total & 100 & 100 & 100 & 100 & 100 & 100 & 100 & 100 \\
\hline Pass Mark & 50 & 50 & 50 & 70 & 67 & $*$ & $70 \#$ & 75 \\
\hline Note: The table shows maximum points possible in each category. \\
\hline
\end{tabular}

Thus, depending on the initial date that a pool of immigrants entered Canada (their epoch), the conditions appearing in Table 1 should be reproduced in the initial entry population. For example, in 1995 mainland China relaxed its exit policies and these new Chinese immigrants entered via the independent entry gate and hence we predict that they should mimic the human capital criteria found in Table 1 circa 1996-2001. In an earlier period, 1986-1996 Hong Kong based Chinese immigrants entered Canada under an earlier set of criteria (business independent class) and we would anticipate that these initial Hong Kong entrants would reflect the extant entry criteria for their historical initial entry epoch. In other words, each initial entry period for any Chinese sourced immigrant group would be doubly selected and have human capital characteristics which reflect their appropriate time dated entry grid and these characteristics should exceed those found in the resident Canadian population. ${ }^{3}$

After the initial entry episode the human capital characteristics for subsequent arrivals from the same origin country will deteriorate for two reasons. First, the double selection procedures will be less selective than in the initial instance. That is, the best immigrants will have left first (Shi, 2004). Their followers will still qualify but at a lower standard. In the next

\footnotetext{
${ }^{3}$ Double selection occurs as the immigrant self selects to leave for Canada and then when Canada assesses the immigrant prior to arrival for her human capital characteristics as outline in table 1.
} 
episode, family reunification will begin after 5 to 7 years and the entrants in this group will have a substantially weaker human capital stock and perform poorly in the labour market (DeVoretz \& Pivnenko, 2004). In short, family class members are singly selected, namely by themselves. ${ }^{4}$

The effect of time and the movement from doubly selected immigrants to the singly selected group can be predicted from an inspection of Figure 1. The initial entry group who are doubly selected would perform over their lifetime along the "Immigrant Earnings Optimistic" line since they would have a greater human capital endowment and motivation owing to the double selection nature of this early arrival group. In other words this group would quickly "catch-up" to the earnings of the native-born at X who are not selected and then surpass them for the rest of their lives. In the absence of "double selection” the "Immigrant Earnings Pessimistic" curve arises due to the fact that they do not pass through the "points grid" and hence have little or no human capital. Thus, these singly selected family members rarely "catch-up" to the nativeborn cohort.

\section{Figure 1: Age-Earnings Gap}

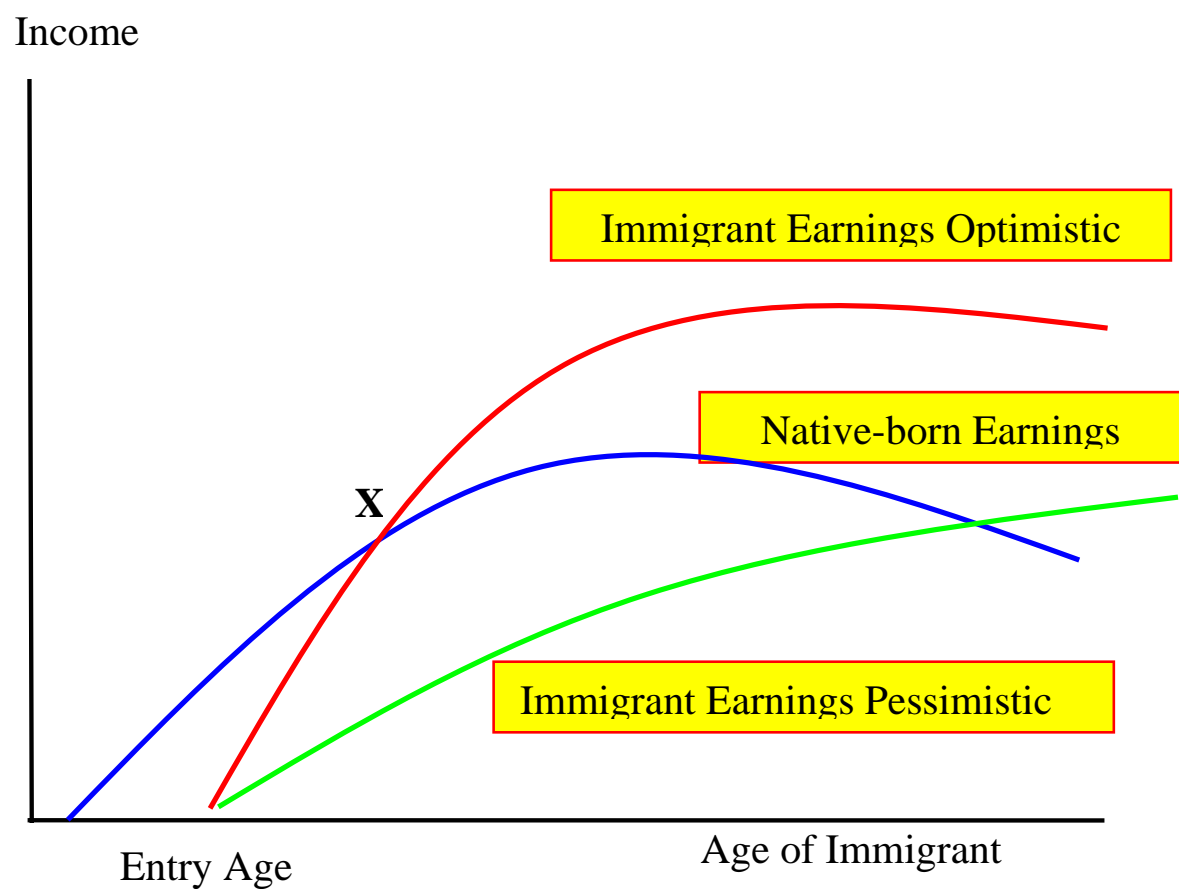

In sum, the combination of Canada's selection system and the gradual and inevitable switch from doubly selected to singly selected immigrants from any one source region will lead

\footnotetext{
${ }^{4}$ The independent immigrant who sponsors his/her relatives must wait until their income performance exceeds the low income cut-off of the resident population in their community. This typically takes 5 to 10 years to reach this point of economic affluence.
} 
to a collapse in human capital and earnings by later immigrant cohorts from any one country. We will test this episodic theory with its inherent periods of double and single selection outcomes on our three waves of Chinese immigrants below. If this theory holds, then heterogeneity in the various Chinese populations should arise as a by product of the selection criteria that screens them at the time of arrival.

\section{Contextual Information}

\section{History of Chinese Immigrants in Canada: Pre-1980}

The Chinese diaspora in Canada is one of the oldest ( $\mathrm{Li}, 1998)$. Con et al. (1982) claim that the first group of Chinese arrived in Victoria on June 28, 1858 from California in search of gold. Originally these people came predominantly from the southern Chinese coastal provinces of Guangdong (or Kuangtung) and Fujian (or Fukien). Most of them were single men from rural areas. They came as coolie workers and chain migrants. As the gold fields petered out, the Chinese found employment as domestic servants, coal miners, and seasonal workers in the salmon canning industry (Tan \& Roy, 1985). Also similarly Chinese workers were used extensively during the construction of the Canadian Pacific Railway (CPR).

With the completion of the CPR, Chinese workers were no longer welcome. In 1885, the government of Canada imposed a $\$ 50$ head tax on all incoming Chinese to control their entry. The head tax was increased to \$100 in 1900 and to \$500 in 1903. When it was found that the head tax was not effective enough to keep the Chinese from immigrating to Canada, the Federal Government passed a restrictive Chinese Immigration Act in 1923, which virtually prohibited all Chinese immigration into Canada until its repeal in 1947. Besides the head tax and the 1923 Chinese Immigration Act, the Chinese also faced other kinds of discrimination. Since they were not allowed to become citizens they could not vote, and they were prohibited from entering certain professions, such as law, medicine, or accounting. Further, they were denied the opportunity to acquire Crown land (Tan \& Roy, 1985).

At this juncture, it should be pointed out that the Chinese population in Canada was “characterized by dualities," divided between those who came to Canada before 1923 and those who came after the introduction of the point-immigration system in 1967 (Con et al., 1982, p.250). Many of the Chinese immigrants who arrived after 1967 were from urban areas and welleducated. They came predominantly from Hong Kong. 


\section{Canadian Immigration Policy}

Changing Canadian immigration policies altered the social and political pressures which attracted or precluded Chinese immigration, and are reviewed below.

From Confederation in 1867 to the 1960s, the selection of immigrants was based on their racial background. The British and Western Europeans were the most "desirable" citizens, the Asians the "unassimilable” and, therefore, "undesirable.” According to Knowles (1997), after World War II Canadian immigration policy continued to be "highly restrictive," despite external and internal pressures for an open-door policy.

In the mid-1960s, Canada was still experiencing a great "postwar boom” (Whitaker, 1991, p.18). Skilled labour was required to help Canada build its expanding economy, but Europe as the traditional source of immigrants was not able to meet Canada's needs. Thus, the Canadian government turned its recruitment efforts to the traditionally restricted areas - Asia. In 1967 a "point system" was introduced by the Liberal Government, which based the selection of immigrants on their "education, skills and resources" rather than on their racial and religious backgrounds (Ibid., p.19). Whitaker further argues that the "point system" was successful in reversing the pattern of immigration to Canada from Europe to Asia. By the mid-1970s there were more immigrants arriving from the Third World than from the developed world, the largest number coming from Asia, followed by the Caribbean, Latin America, and Africa (Ibid. p.19). Among the Asian group, many were from China. In fact, $\mathrm{Li}$ (1998) states that Canada admitted 30,546 Chinese immigrants between 1956 and 1967, increasing to 90,118 between 1968 and 1976 after the introduction of the point system.

\section{Chinese Emigration}

It is also important to examine the "push" factors that drove Chinese from their home “country”. As Li (1998) points out, the majority of the Chinese immigrants originated from three areas: Hong Kong, Taiwan, and China - the focus of this review.

Hong Kong was the primary source of Chinese emigration to Canada after the Second World War (Li, 1998). According to Wong (1992), there have been three major waves of emigration from Hong Kong since the end of the Second World War. The first occurred between 1958 and 1961, owing to dramatic changes in Hong Kong's agriculture. The second wave was triggered by a political crisis, the 1967 riot. It was a spill-over of the Cultural Revolution (19661976) in China. It began with a demonstration led by local communists, but ended with violence 
and terrorism. Threatened by bombs and political instability, thousands left Hong Kong for the United States and Canada. Many of them were members of the Hong Kong elite. The third wave of emigration, described by Wong, began in the 1980s. According to the 1984 Sino-British Agreement on the future of Hong Kong, the colony would become a special administrative region under the rule of China. Many of the residents who were worried about their future began to leave Hong Kong. A large number of them found homes in Canada. Wong described this latest group of emigrants as "predominantly 'yuppies' - young, educated, middle class professionals" (Ibid. p.4).

China had been isolated from the rest of the world since the People's Republic of China (PRC) was founded in 1949. However, two historical events that took place during the 1970s paved the way for substantial emigration from the PRC in the 1990s. The first was the establishment of formal diplomatic relations between Canada and China in 1973, which did not set off an immediate upsurge of emigration from China, though it set the political stage for the movement of people between the two nations thereafter. The other, the death of Mao Zedong in 1976, marked the end of the Cultural Revolution. With Deng Xiaoping's rise to power in 1978, a number of new reforms were introduced. These reforms, generally characterized by an "open door” policy, shifted the nation's focus from political struggle to economic reconstruction. The “open door” policy created the economic conditions for the mobility of Chinese people.

In the 1980s direct emigration from China to Canada was relatively small (Li, 1998). The pro-democracy student movement in 1989 became a catalyst as well as a hindrance for the emigration of Chinese people. On the one hand, the event prompted the Canadian government to issue permanent resident status to many Chinese students and scholars who were studying in Canada during that time. On the other hand, the Chinese government tightened the rules to restrict further mobility. However, this hindrance did not last long.

The 1990s witnessed substantial emigration from China to Canada. China’s “open door” policy and economic development resulted in an economic boom in China and the growth of new middle income class. Combined with the relaxed passport restrictions by the Chinese government, China entered the “emigration phase” (Wallis, 1998). Furthermore, Canada opened its immigration office in Beijing, which processed immigration applications directly from China. Given these developments, the PRC émigrés outnumbered Hong Kong’s and Taiwan’s in 1998, 
as it became the top source region for immigrants to Canada (Citizenship and Immigration Canada, 1999).

Taiwan is a unique case. The influx of emigration from Taiwan has always been closely related to the island's political instability, particularly with regard to Taiwan's relationship with mainland China (Tseng, 2001). Tseng argues that two events in the 1970s influenced Taiwanese people to turn to emigration as a solution to their uncertain future. The one was the withdrawal of the Republic of China from the United Nations and the concomitant acceptance of the People's Republic of China (PRC) as the sole legitimate government in China. The other was the normalization of the relationship between the PRC and the US in 1978, which worried many Taiwanese people. They were concerned that Taiwan might be eventually reclaimed by Communist China. Besides the concern for political instability, emigration from Taiwan may also be understood "as a middle-class response to the problems resulting from the burgeoning export-oriented economy” (Tseng, 2001, p.34). People were unhappy with by the quality of life on the island as a result of its rapid industrialization. According to Kotkin (1993, cited in Tseng, 2001), an estimated 50,000 Taiwanese emigrated between 1985 and 1991, with the United States, Australia, and Canada being the most popular destinations.

The key conclusion from this brief history of Chinese emigration is that episodic immigrant flows were created by these unique push factors which in turn implied that each population faced different immigration policies prior to arrival.

\section{An Overview of the Research Data}

To describe the Chinese émigré population two sources of data are explored: the Landed Immigrant Data System (LIDS) and the Canadian Census of 2001. ${ }^{5}$ It must be emphasized that this analysis covers the period between 1980 and 2001, which, as shown above, represents the most dynamic period of Chinese migration to date. Accordingly, the data set will facilitate the identification of the changing characteristics of Chinese immigrants, including their age, gender, marital status, immigrant class, occupation, country of birth, level of education, Canadian language ability, native language, and economic performance. In order to develop our theme of heterogeneity across space, a cross-tabulation is provided of Chinese immigrants by country of birth as well as over time. The People’s Republic of China, Hong Kong, and Taiwan are used as

\footnotetext{
${ }^{5}$ The LIDS is a database maintained by Citizenship and Immigration Canada (CIC) that contains all landing records of individual immigrants.
} 
country of birth to define these Chinese immigrant groupings. We are cognizant that there are other ways of defining Chinese, such as country of citizenship or country of last permanent residence however, a variety of technical reasons favour this definition. ${ }^{6}$

\section{Report of Findings}

\section{Mapping the National Landscapes}

According to the LIDS records, 755,698 Chinese became Canadian landed immigrants between 1980 and 2001. Over 20\% of them arrived in the 1980s, about 70\% in the 1990s, and the rest came in the new millennium. With respect to gender, $47.9 \%$ were male and $52.1 \%$ female. In terms of age, one quarter (25.6\%) were below 20, 65.4\% between 20 and 59, and 9\% 60 years and older. ${ }^{7}$ As for marital status, more than half were married (53.2\%), and 42.7\% were single. The rest were widowed, divorced, separated, or common law partners. Regarding their immigrant entry class, the largest group came under the rubric of the independent class (30\%), and then via the family class (27\%), followed by assisted relative (12\%), entrepreneur (11\%), and investor classes (8.6\%). In terms of occupations, professionals in the natural and applied sciences represented the largest occupational group (9\%).

With respect to country of birth, almost one half of the Chinese immigrants came from the People’s Republic of China (49.7\%), while the other half was divided unevenly between Hong Kong (37.5\%) and Taiwan (12.4\%). Also, in terms of citizenship, before moving to Canada the immigrants were citizens of 132 countries, from Afghanistan to Zimbabwe, but the majority were subjects of either China (34.4\%), the British Dependent Territories (i.e., Hong Kong, 25.3\%), or Taiwan (13\%). Another 13\% were connected with Britain (British National Overseas, UK \& Colonies, and British). In sum, Chinese immigrants to Canada, as defined by

\footnotetext{
${ }^{6}$ Because of its colonial connection with Britain before 1997, many Hong Kong residents also hold UK passport. Therefore, defining by country of citizenship is problematic for the Hong Kong immigrants. We also considered the possibility of using country of last permanent residence. We opted it out because defining by the country of last permanent residence, no matter how briefly you stayed, may be a by product of the immigrant's earlier decision to accumulate human capital in his/her birth country. We note that we are analyzing adult immigrants whose human capital accumulation was probably finished before any moved on, thus country of last permanent residence would be irrelevant in influencing this crucial characteristic of human capital accumulation. In fact, independent runs based on last permanent residence showed that human capital accumulation was not affected by this definition vis a vis country of birth. In the absence of knowing when people moved to their country of last permanent residence and thus how long they stayed there, we opted for the unambiguous country of birth definition of Chinese status.

${ }^{7}$ This corresponds to the 2001 Census which shows the majority of Canada's newest immigrants as in the workingage category (Statistics Canada, 2003).
} 
source area, were not a homogeneous group. They came from many different parts of the world in different time periods and as a by product of the push forces outlined above.

LIDS also records the level of education and language abilities of Chinese immigrants upon arrival. About 39\% had 9 years of schooling or less at the time of immigration, 18\% had finished high school, and 43\% had post-secondary education. Among the last group, 15.4\% received a bachelor's degree, 6.2\% had either a master's or doctorate degree. Of those speaking their native languages, 58\% spoke Cantonese, 30\% Mandarin, 9\% Chinese, and the rest, 3\% spoke 98 different languages and dialects from Afrikaans to Yiddish. It was not clear what the reported 9\% included. It could have Mandarin and/or Cantonese and other dialects. As to the Canadian language abilities, 41.7\% spoke English, while 57.7\% spoke neither English nor French.

According to the 2001 Census of Canada (Statistics Canada, 2003), 94\% of immigrants who arrived during the 1990s were living in Canada's census metropolitan areas. Among them, nearly three-quarters (73\%) lived in just three census metropolitan areas: Toronto, Vancouver and Montréal. The LIDS records show that between 1980 and 2001, 87\% of the total Chinese immigrants to Canada landed in its five largest metropolitan cities. ${ }^{8}$ Toronto attracted the largest group (41\%), followed by Vancouver (31\%), Montreal (7.8\%), Calgary (4\%), and Edmonton (3.2\%). This distribution reflects the trend toward immigrant settlement in Canada's major urban centres. However, the percentage of Chinese immigrants who arrived in Canada's three largest cities (80\%) was even higher than that for all immigrants to Canada.

\section{Grouping by Year of Landing}

Central to our theoretical argument is that the episodic movement of various Chinese populations ultimately led to the heterogeneous nature of the Chinese population in Canada. Figure 2 groups Chinese movement to Canada according to the year of landing and country of birth. The twenty-two year duration from 1980 to 2001 was divided into four periods: 19801985, 1986-1990, 1991-1995, and 1996-2001. This disaggregation is an attempt to measure the changing characteristics of Chinese immigrants by entry period and to amplify our episodic entry theory.

The cross tabulation reveals that from 1980 to 2001 there was a steady increase of Chinese immigrants during each period, with the smallest gain during the first period (9.4\%) and

\footnotetext{
${ }^{8}$ This may not necessarily reflect their residency, as internal migration can take place after arrival.
} 
the largest gain during the last period (37.5\%). Based on country of birth, the intake from China remained at the same level during the first two periods and then experienced a sharp increase during the last two periods (1991-1995, and 1996-2001). In the case of Hong Kong, there was a steady increase up to 1991-1995, and then a sharp decline in the late 1990s. The number of immigrants from Taiwan was relatively small; nevertheless it gradually increased over the period as Figure 2 shows. Thus, by defining our Chinese sample by country of birth, we can clearly depict our episodic entry path for each individual country/region.

Figure 2: Grouping by Year of Landing and Country of Birth (1980-2001)

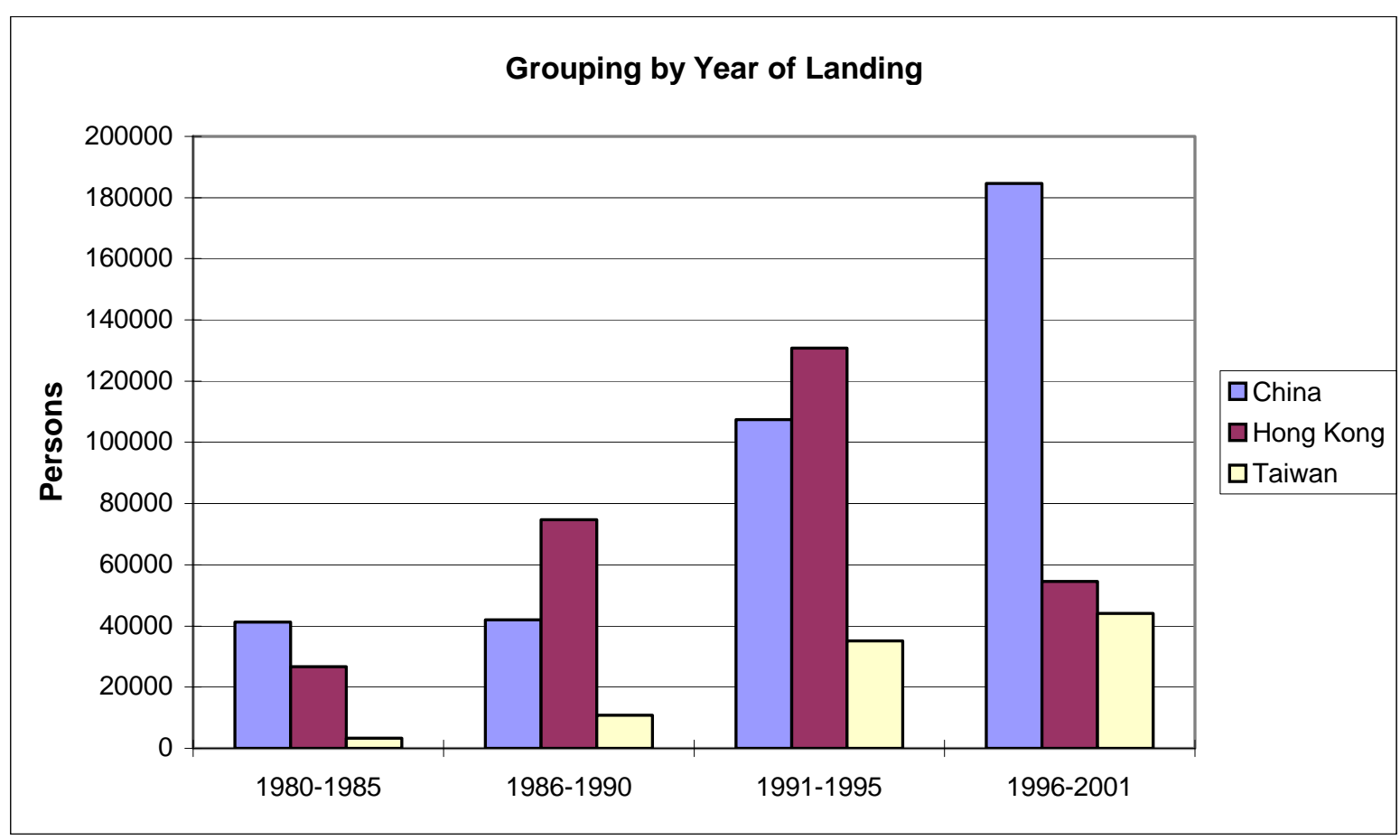

Source: Landed Immigrant Data System, 1980-2001

With respect to the age structure of Chinese immigrants, the most noticeable change was found in the group from China. While the number in the age group 20-39 increased significantly, from $27.8 \%$ during $1980-1985$ to $58.2 \%$ during 1996-2001, the number of older immigrants (60 years and older) had concomitantly decreased from 26.3\% in 1980-1985 to 6.6\% in 1996-2001. In sum, immigrants from Mainland China were the youngest which reflects the importance of the age criterion in the selection process they faced as primarily independent immigrants.

A cross tabulation by immigrant entry class and year of landing (Figure 3) yields some surprising results, the most significant of which is the number of independent class immigrants emanating from Mainland China. The size of the independent class jumped from 3.6\% during 
1980-1985 to 58.5\% during the late 1990s, representing a 54.9\% increase. For all three groups, the number of immigrants entering via the family class decreased dramatically (23-30\%). This trend clearly shows Canada's preference for independent immigrants vis a vis family class immigrants in the 1990s and the effect of the episodic arrival of Mainland Chinese.

The changing Chinese occupational distribution is also revealing. In the early 1980s, mainland Chinese immigrants largely had occupational backgrounds in primary industries, manufacturing, and sales and services. The 1990s witnessed a dramatic occupational change. By 1996-2001, 25.3\% of mainland Chinese immigrants had a professional background in the Natural and Applied Sciences before moving to Canada. In contrast, Hong Kong (3.7\%) and Taiwan (8.8\%) had only small shares for professionals. The Taiwanese group had an inconsistent entry pattern, which deserves attention. Between 1986-1990, entrepreneurs (44.1\%) were the largest group of immigrants from Taiwan; later (1991-1995) the investor class (45.7\%) became the largest entry group; and finally during the 1996-2001 period independent Taiwanese immigrants (45.4\%) formed the top entry class.

Figure 3: Grouping by Year of Landing and Immigrant Class (1980-2001)

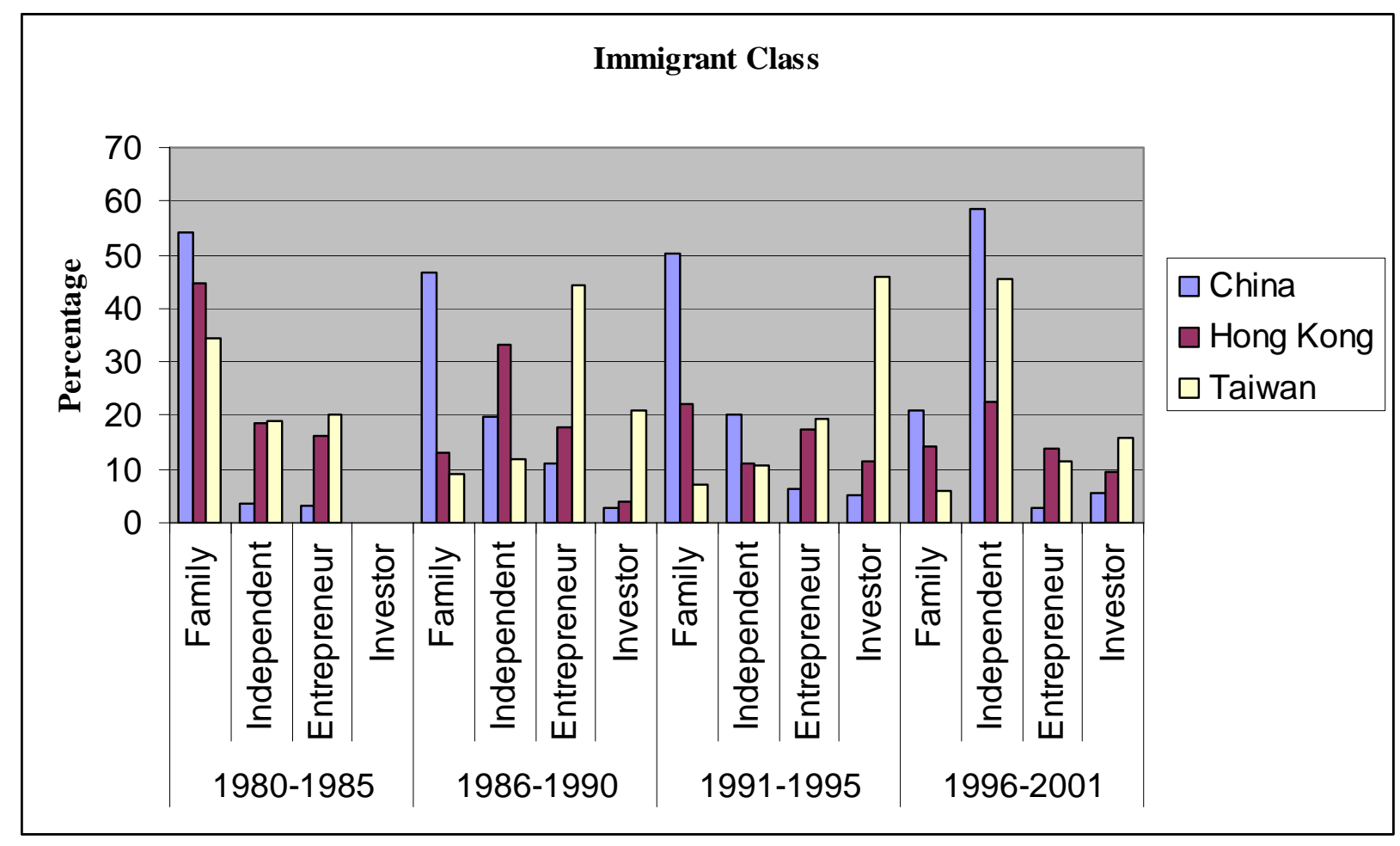

Source: Landed Immigrant Data System, 1980-2001 
The data further reveals a clear pattern of Chinese educational attainment. There was a general decrease in the number of people with 0-9 years of education and an increase in those with post-secondary education. However, it is the mainland Chinese group which again stands out and confirms our episodic theory of double selection. From 1980-1985, the number of mainland Chinese immigrants with $0-9$ years of education accounted for $65.4 \%$ of arrivals while that number dropped to $30.9 \%$ during the 1996-2001 period. In contrast, during 1980-1985 only $19.4 \%$ of the immigrants from China had acquired post-secondary education, and that number jumped to 60.5\% during 1996-2001 (Figure 4), resulting in a significant “brain gain” to Canada.

Figure 4: Group by Year of Landing and Level of Education (1980-2001)

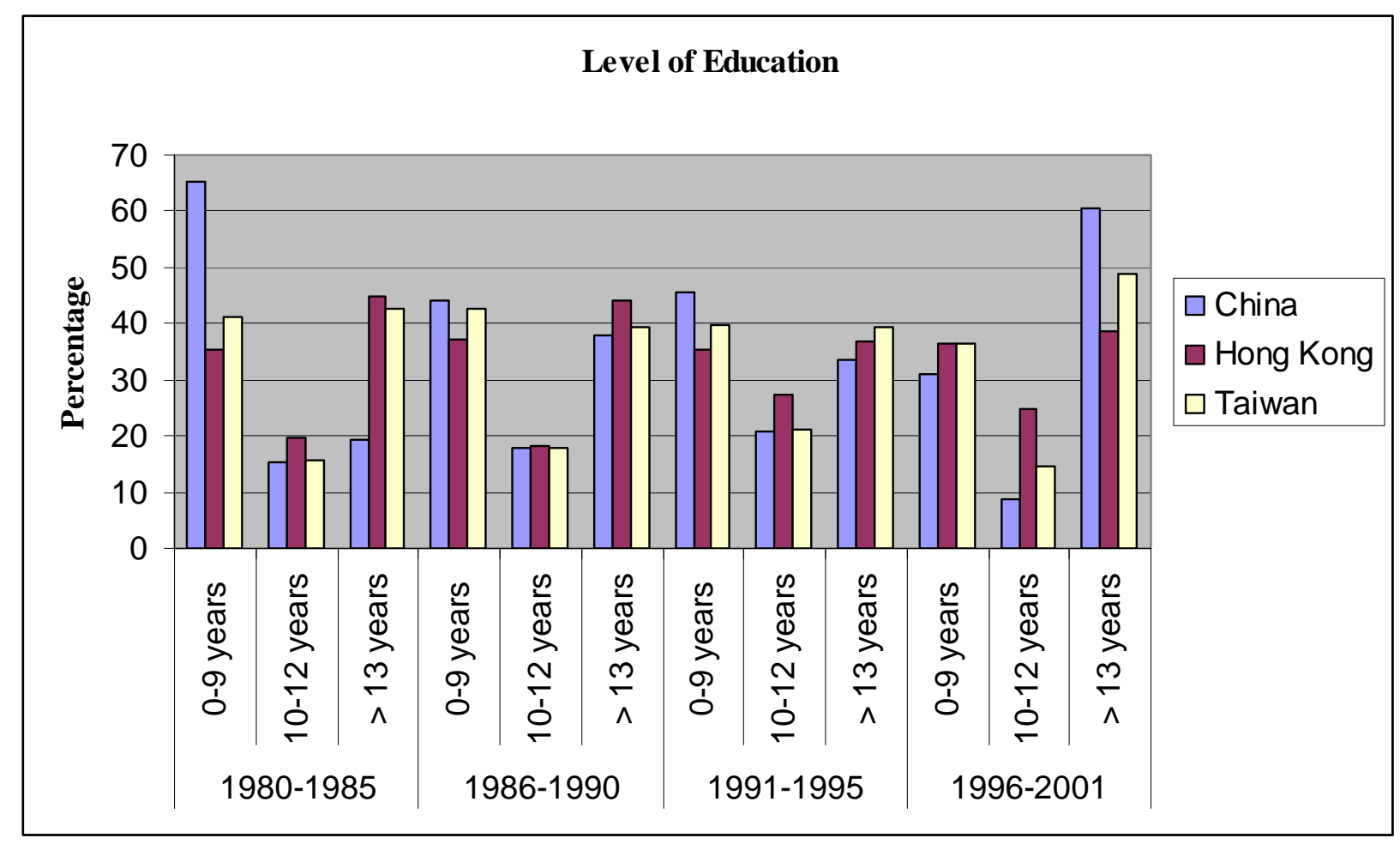

Source: Landed Immigrant Data System, 1980-2001

Among all three groups, the mainland Chinese came to Canada with the lowest level of English proficiency and the Hong Kong Chinese had the highest, with more than half of them self reporting speaking English. A breakdown by year of landing shows that more mainland Chinese spoke English in the 1990s than earlier mainland cohorts. For example, during the 19801985 period, only $10.9 \%$ of the mainland Chinese spoke English; and that number increased to $35.4 \%$ circa 1996-2001. This trend again supports the prediction of our episodic entry theory. 
Figure 5: Grouping by Year of Landing and Canadian Language Abilities (1980-2001)

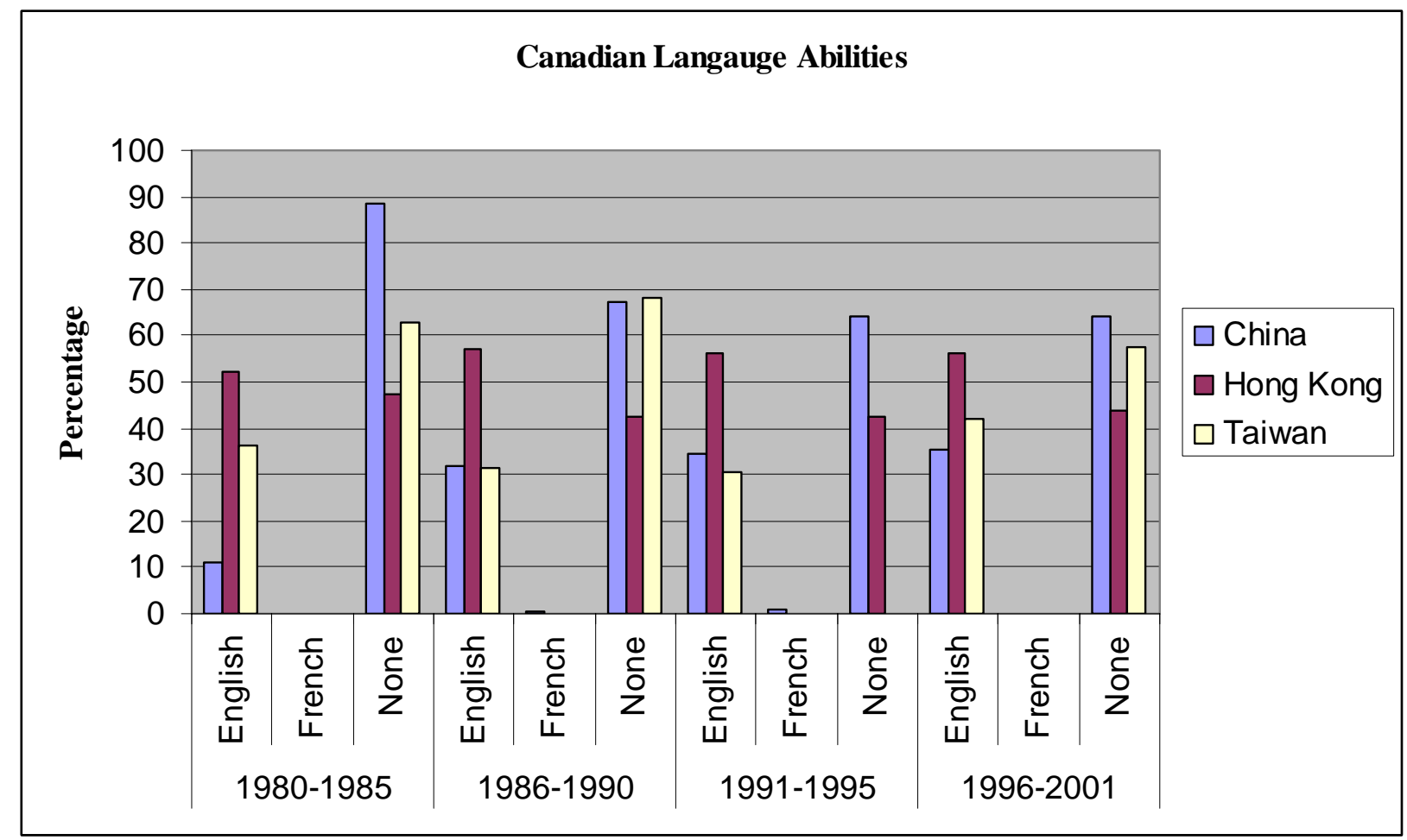

Source: Landed Immigrant Data System, 1980-2001

With respect to the Chinese immigrants' native language abilities, two important developments are noteworthy. One is the increase of Mandarin speakers among immigrants from mainland China and Taiwan, and the concomitant decrease of Cantonese speakers. The case of China is most noticeable. Among all who arrived in Canada from China during 1980-1985, 88.1\% identified themselves as Cantonese speakers and only 4.1\% claimed to be Mandarin speakers. This composition reversed itself by 1996-2001 when 60.5\% of Mandarin speakers and $16.5 \%$ of Cantonese speakers arrived. Until 1996, the majority of mainland Chinese immigrants came from the traditional Cantonese-speaking areas of Guangdong Province. In the case of Taiwan, the high percentage of Cantonese speakers in the 1980s is owing to the fact that these families moved to Taiwan with the Chinese Nationalist government in the 1940s.

In sum, the cross tabulation by year of landing initially showed enduring connections with past Chinese immigration flows followed by an abrupt break in these patterns. During the 1980s, there were more older immigrants from mainland China, more family class immigrants, more unskilled workers, and fewer with post-secondary education or English skills than the other two groups (also see Appendices 1 \& 2). Another connection with the past was the high percentage of Cantonese speakers among the mainland Chinese up to 1996. It reflected an 
association with the traditional source of Chinese immigrants from the Guangdong province of China. However, almost all these patterns reversed themselves in the 1990s. For example, during the 1996-2001 period an unprecedented number of independent immigrants from China (58.5\%) were admitted into Canada; and a quarter of them were professionals in the Natural and Applied Sciences (also see Appendix 4). Also during the same period, a large percentage Chinese from mainland China (PRC) came with a high degree of post-secondary educational attainment (60.5\%). Furthermore, the number of Cantonese speakers dropped to 16.5\% during 1996-2001 from a peak of $88.1 \%$ during $1980-1985$; while the number of Mandarin speakers rose concomitantly to $60.5 \%$ from $4.1 \%$ across the same two periods confirming the effects of the episodic movements of the immigrants coupled with Canada's extant selection policy.

\section{Economic Performance}

From the discussion above, which details the changing patterns of ethnic Chinese immigration to Canada over the last 22 years, it may be concluded that the Chinese immigrant population is diverse in terms of social and human capital characteristics. However, it may be asked if this heterogeneity in human capital attributes has led to a heterogeneity in labour market outcomes. We attempt to answer this question below with an analysis of available census data.

Figures 6 to 8 provide a template for an analysis of the labour market outcomes for these diverse members of the Chinese diaspora. These census-based figures report total income ${ }^{9}$ as opposed to wage and salary income to capture the Chinese diaspora's overall economic welfare across the age spectrum for recent arrivals (5 years or less) from Hong Kong and Mainland China. Taiwan is our other target group of interest, but cannot be distinguished with the PUMF (Public Use Microdata Files) version of the 2001 census and is thus dropped. Several observations are apparent.

First, total income in Figure 6 reveals differences across countries of origin. The peak income of PRC Chinese was \$20,000 and \$25,000 for Hong Kong Chinese. The latter group earnings peak earlier (26-30) while the PRC group peaks at a later age (36-40).

\footnotetext{
${ }^{9}$ Total income includes earnings from the following sources: (i) wages and salaries, (ii) net farm self-employment income, (iii) net non-farm self employment income, (iv) federal child tax benefits, (v) old age security pension and guaranteed income supplement, (vi) Canada or Quebec Pension Plan benefits, (vii) benefits from Unemployment Insurance, (viii) other income from government sources, (ix) dividends, interest on bonds, deposits and savings certificates and other investment income, (x) retirement pensions, superannuation and annuities including those from RRSPs and RRIFs, and (xi) other money income.
} 
Figure 6: Age Income Profile (Total Income): 0-5 Years in Canada

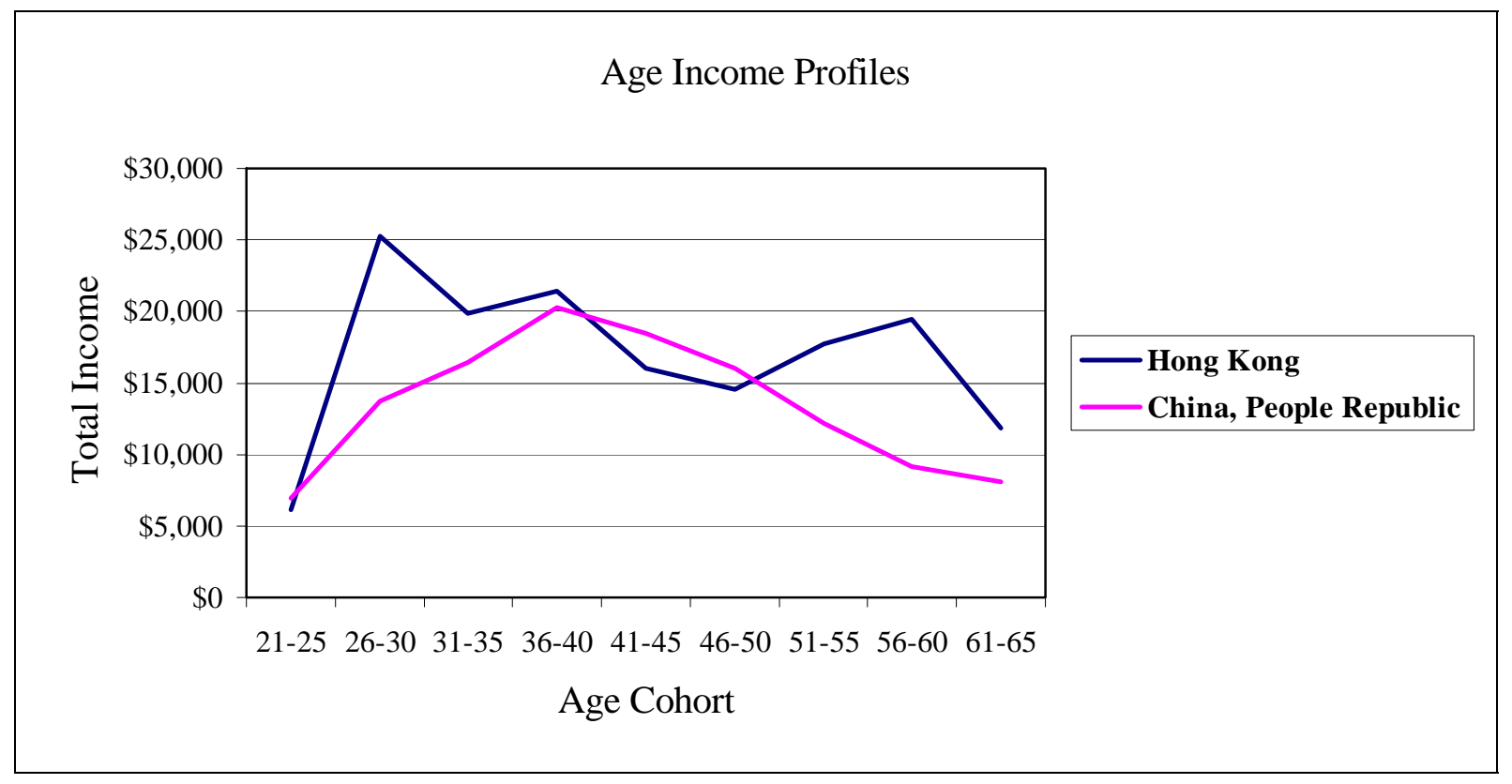

Source: 2001 Census of Canada, Public Use Microdata File for Individuals

Second, Figures 7 and 8 begin to reveal the heterogeneity contained in the Chinese diaspora by gender. Regardless of source country, Chinese males earn substantially more than Chinese females with a variety of peak earning points across entry groups.

Figure 7: Age Income Profile (Total Income): 0-5 Years in Canada, Female

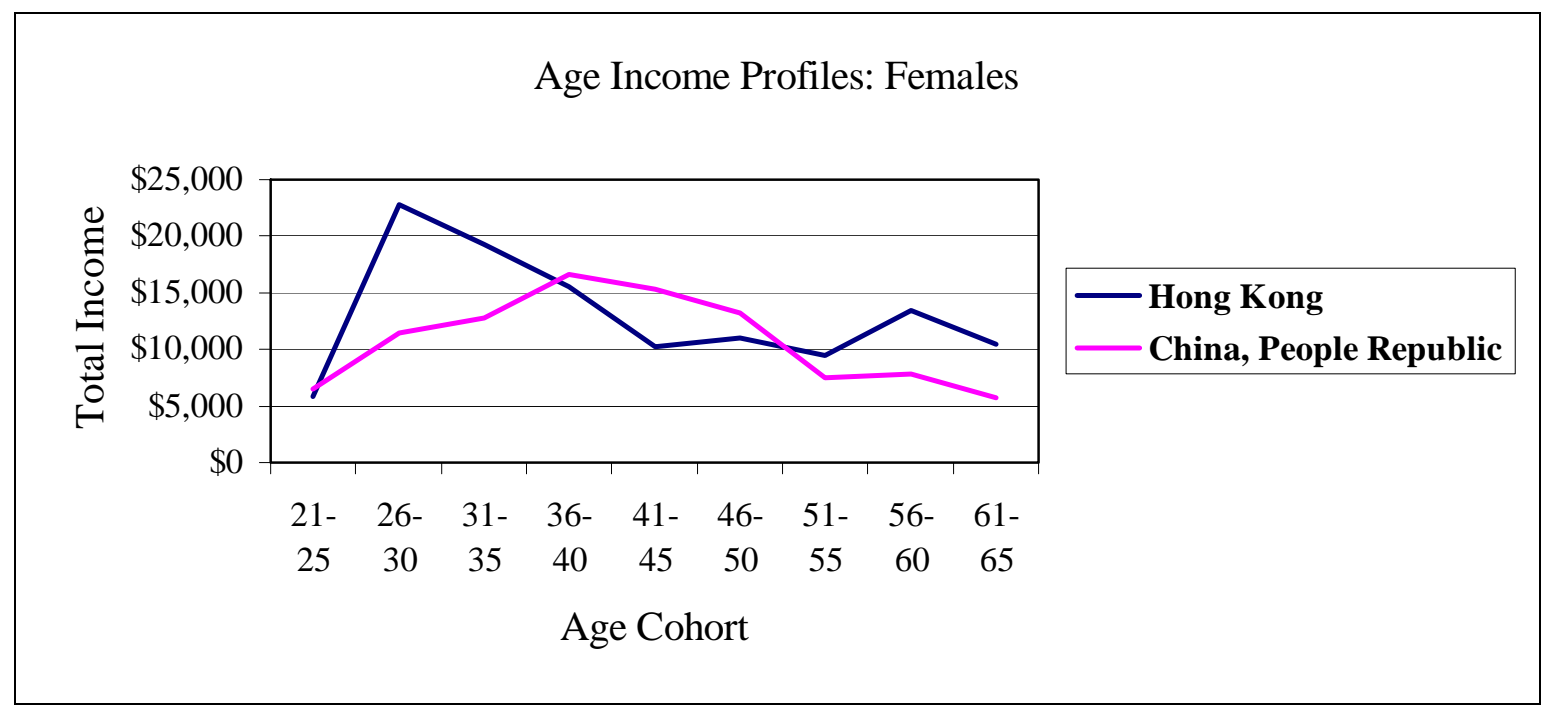

Source: 2001 Census of Canada, Public Use Microdata File for Individuals

Third, this early peak in the female age earnings profile is in sharp contrast to the late (36-40) peak for male arrivals from the P.R. China and Hong Kong.

Figure 8: Age Income Profile (Total Income): 0-5 Years in Canada, Male 


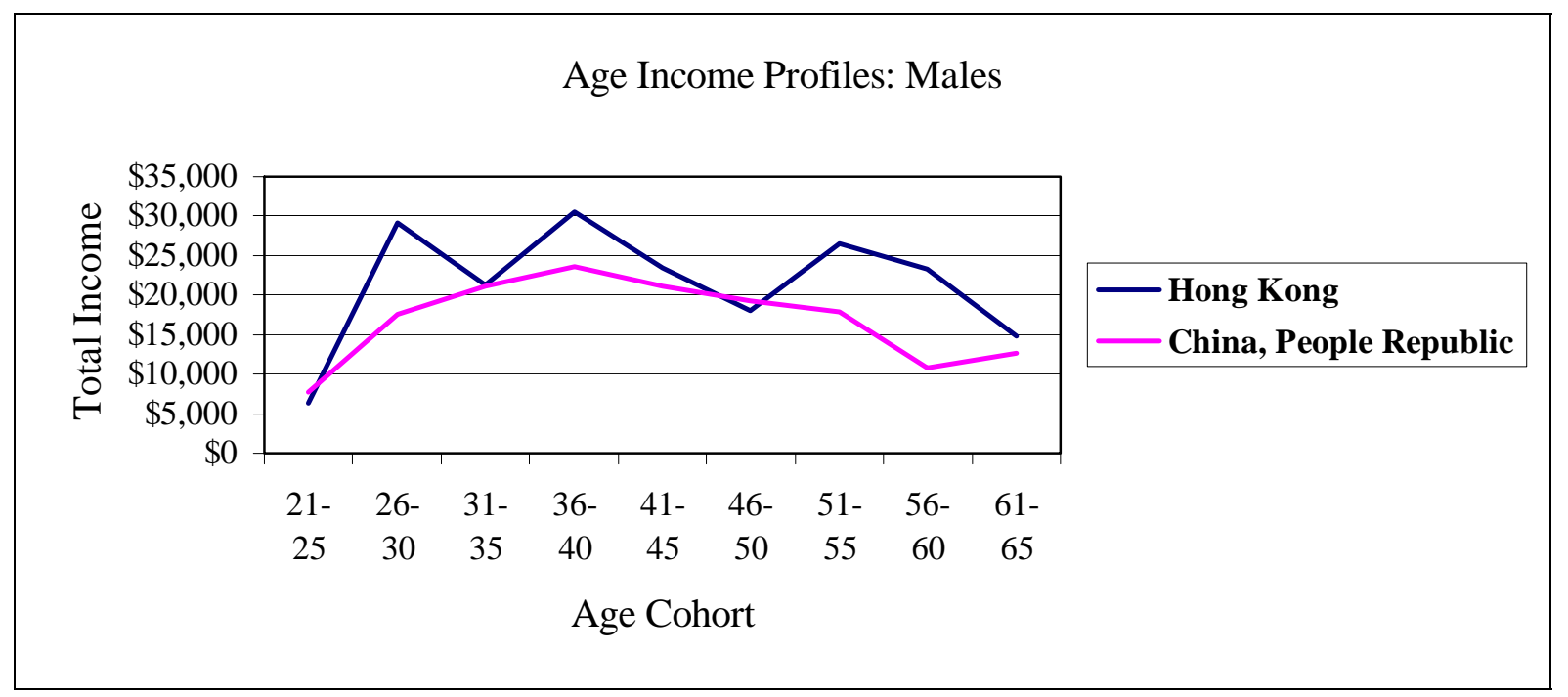

Source: 2001 Census of Canada, Public Use Microdata File for Individuals

If we analyze wage and salary received rather than total income earned, a more accurate picture of the effect of human capital characteristics on labour market performance results. Our expectation is that wage and salary earnings will be lower and exhibit greater heterogeneity across the Chinese diaspora, given their different levels of human capital attainment upon arrival in Canada. Figures 9-11 respectively report the wages and salaries for Chinese from various origins by gender.

First, there is a marked difference in reported total income and total earnings from wages and salaries for recent arrivals ( $0-5$ years). The wage and salary income for recent Chinese arrivals, which better reflects the rewards derived from their linguistic and human capital characteristics, reveals that these rewards are extraordinarily low, particularly for the PRC group. A gender decomposition reveals that male wage and salary income (Figure 10) exceeds the profile for females in Figure 10.

Figure 9: Age Earnings Profile (Wages \& Salaries): 0-5 Years in Canada 
Age Earnings Profiles

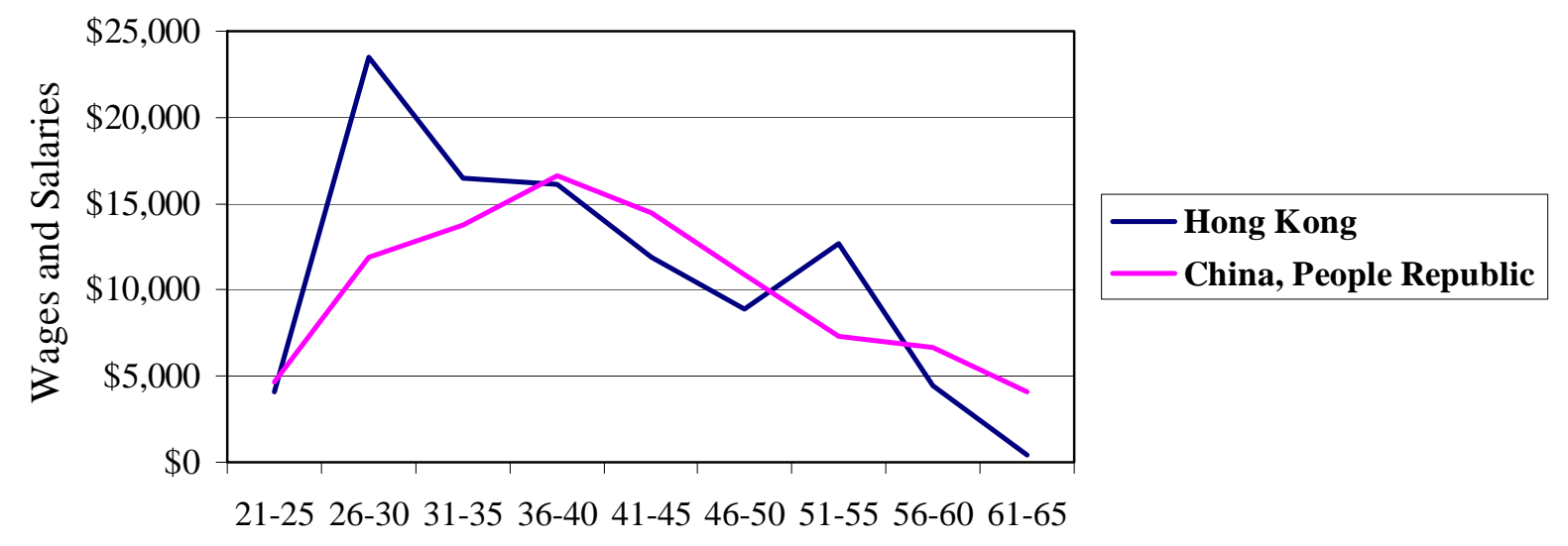

Age Cohort

Source: 2001 Census of Canada, Public Use Microdata File for Individuals

Figure 10: Age Earnings Profile (Wages \& Salaries): 0-5 Years in Canada, Male

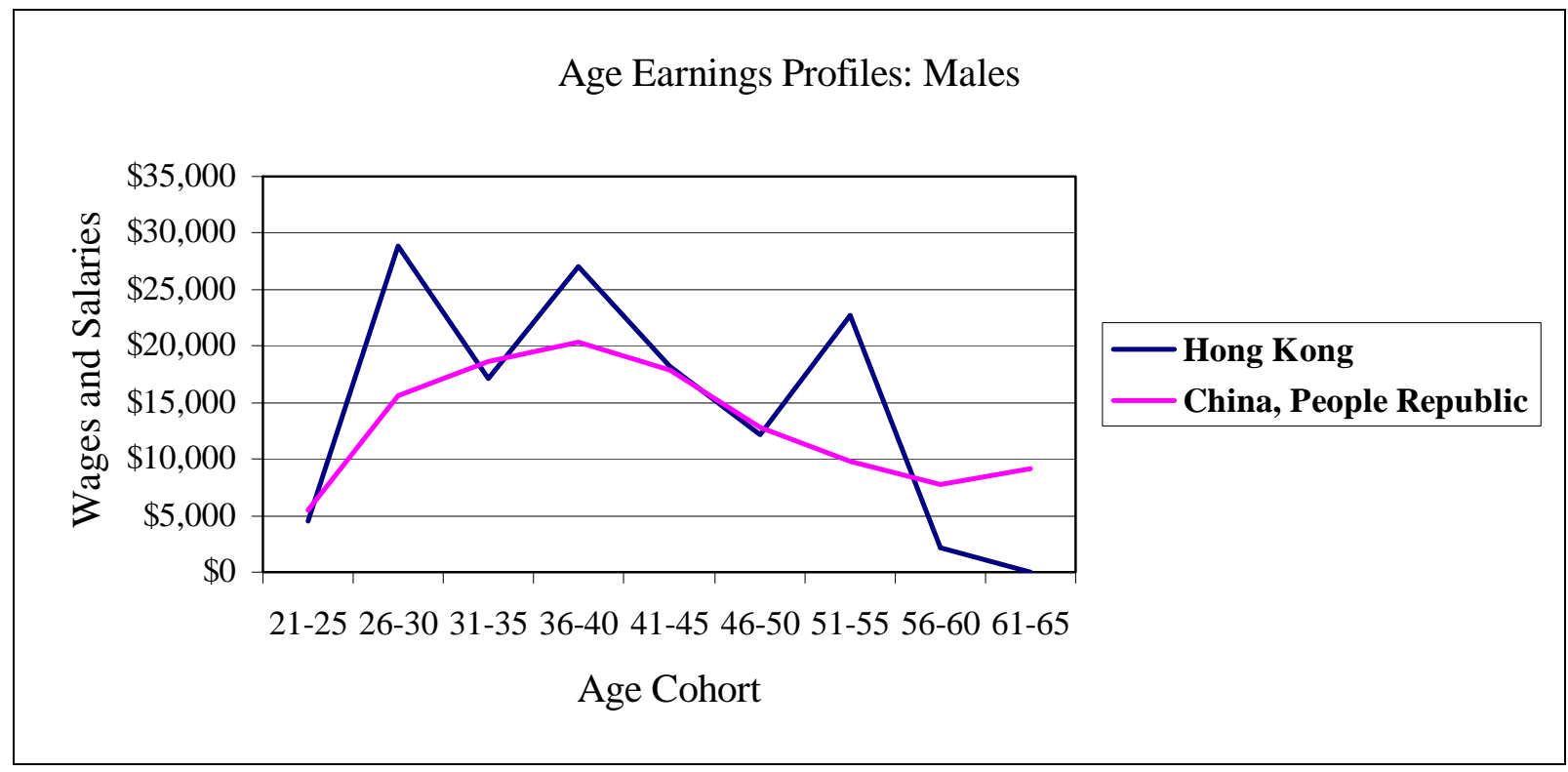

Source: 2001 Census of Canada, Public Use Microdata File for Individuals

Second, female wage and salary earnings of recent arrivals as reported in Figure 11 collapse after age 40 and dramatically reveal the weak labour market performance of older female Chinese, especially from Hong Kong. 
Figure 11: Age Earnings Profile (Wages \& Salaries): 0-5 Years in Canada, Female

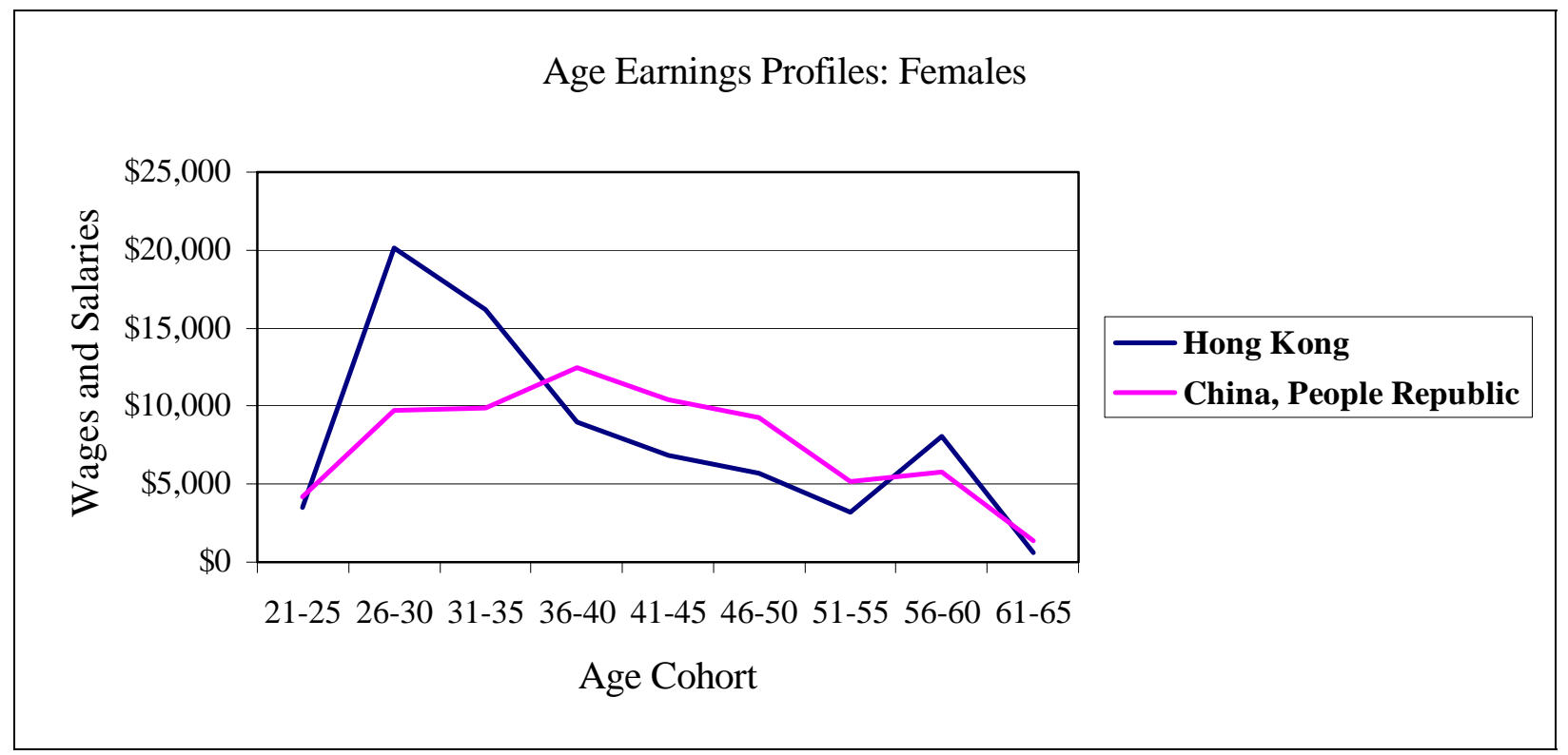

Source: 2001 Census of Canada, Public Use Microdata File for Individuals

At this point we conclude that substantial heterogeneity of labour market performance is observed across age and gender for all recent (0-5 years in Canada) Chinese arrivals. We now explore earnings for a variety of entry cohorts to portray the effects of time in Canada.

Figures 12 and 13 dramatically portray the economic heterogeneity across the life cycle of Chinese immigrants by their tenure in Canada. If the analysis is based on the wage and salary performance of Chinese immigrants from Hong Kong (Figure 12), the startling collapse in wages and salaries earned by the youngest vintage of immigrants (0-5), as compared with the two older immigrant vintages becomes evident. For example, at age 46-50 the older two vintages of immigrants earned between $\$ 15,000$ and $\$ 29,000$ while the youngest vintage earned on average less than $\$ 15,000$.

Figure 12: Income Comparison by Years in Canada - Hong Kong 


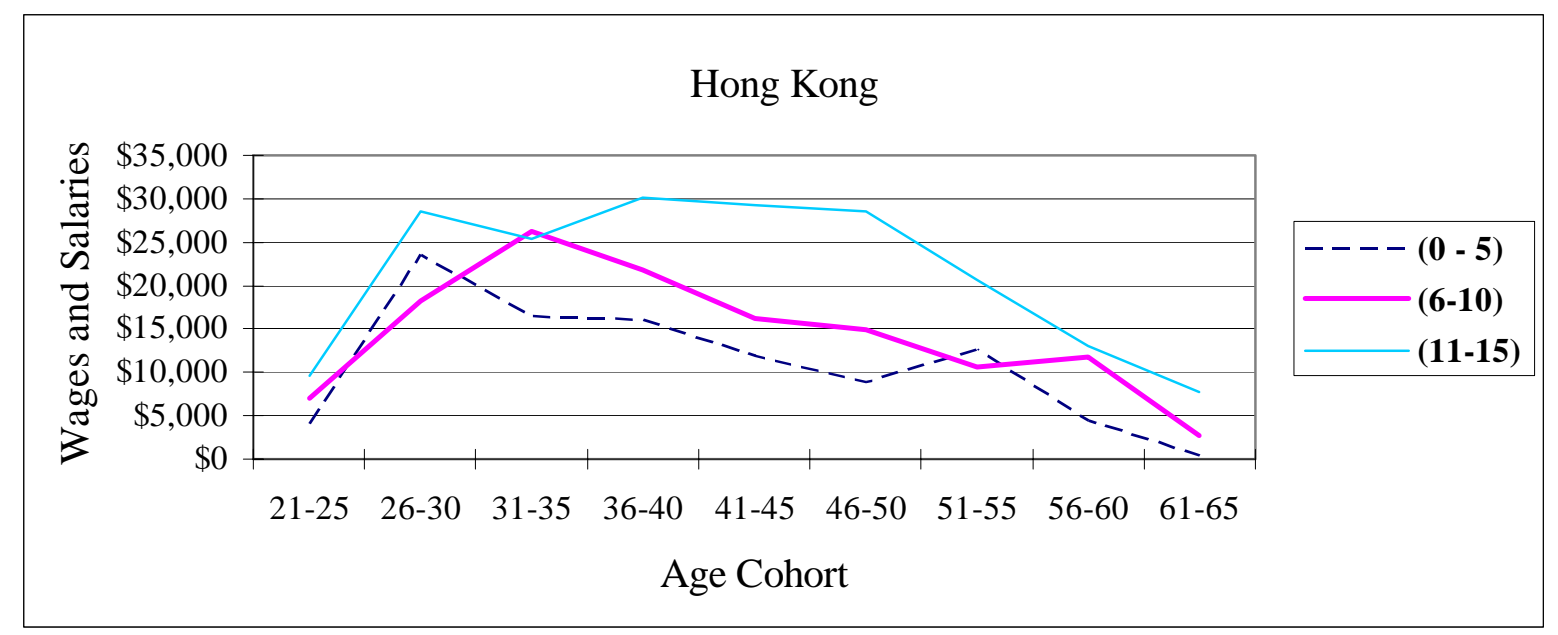

Source: 2001 Census of Canada, Public Use Microdata File for Individuals

Figure 13 shows the wage and salary earnings by entry cohort for Chinese immigrants from the mainland (P.R. China). Here, the older vintage group (11-15 years in Canada) generally outperforms the two more recent vintages from both the PRC and Hong Kong. In sum, years of residence in Canada greatly affects Chinese wage and salary earnings. The newest vintage earnings simply collapse, especially for (unreported) female PRC immigrants.

Figure 13: Income Comparison by Years in Canada - PRC

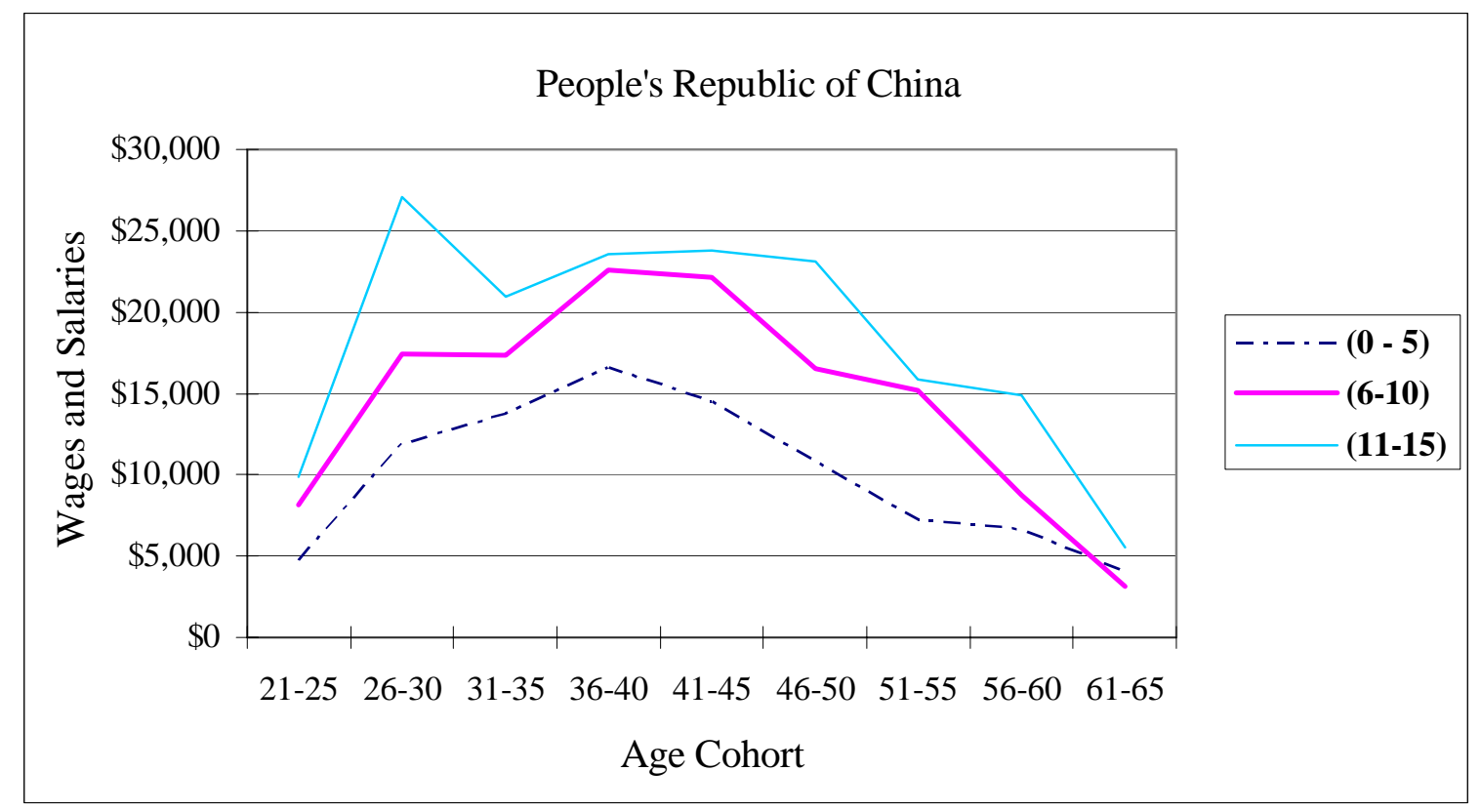

Source: 2001 Census of Canada, Public Use Microdata File for Individuals

\section{Conclusions}


Chinese immigrants to Canada are no longer a homogeneous group from the rural areas of Mainland China. Instead, this study reveals significant subgroup differences. It shows that immigrants from Hong Kong share more commonalities with those from Taiwan than with those from mainland China. Even among the mainland Chinese themselves, there were significant differences between the 1980s and the 1990s. One noteworthy development was the recent arrivals from the People's Republic of China, many of whom came with post-secondary education and entered Canada as professionals.

These changing characteristics of Chinese immigrants to Canada reflect, and were shaped by Canada’s immigration policies. The 1978 Immigration Act removed discriminatory immigration barriers and made it possible for skilled Chinese to enter Canada. In particular, as successive new regions emerged to supply Chinese immigrants predictable patterns now appeared. The first immigrant wave to Canada, regardless of origin, was doubly selected under Canada's independent or points driven admission category and hence these immigrants arrived with substantial human capital. However, the inevitable successive immigrant waves in the family class from the same region had less human capital since they were singly selected.

A series of other policy changes affected Chinese immigrant flows to Canada. The introduction of the Business Immigration Program in 1985 attracted a large number of entrepreneurs and investors from Hong Kong and Taiwan. In addition, since the mid-1990s, the Canadian government strengthened the policy "to place a higher premium on independent or economic immigrants because they were deemed to bring a greater economic value to Canada than those admitted under the family class or the refugee class” (Li, 2003, p.43). This shift in policy has clearly influenced the rise of economic immigrants and the drop of Chinese immigrants who were admitted in the family reunification class. In particular, the sharp increase of independent immigrants from mainland China during 1996-2001 reflects this policy change.

In addition to the policy driven forces, changes in the political climate in the source areas have also shaped Chinese immigrant patterns to Canada. The 1989 student movement in China and the 1997 return of Hong Kong to China are two good examples of supply changes. These episodic events created new supplies of Chinese immigrants who in turn were first doubly and then singly selected by Canadian immigration policy leading to the human capital characteristics observed. 
The economic consequences of Canada’s immigration policy, however, do not match the human capital outcomes of Canada's screening policy. The historical experience of an immigrant earnings “catch-up” does not hold. In particular, an analysis of recent Chinese immigrants indicates that they have substantial human capital endowments, but they are clearly failing in the labour market.

What are the policy implications of this study? First, the extant immigrant selection grid used to screen independent Chinese immigrant applicants was successful in selecting immigrants with seemingly substantial human capital endowments. However, the selection system has not been able to provide a good job match such that these qualifications would lead to successful employment. In short, Canadian entrepreneurs fail to recognize the qualifications valued in the immigrant selection process. This market failure requires aggressive Canadian government action in terms of credential evaluation and recognition programs after the immigrant's arrival. In addition, mentoring programs must be put into place both to provide "bridge gap" training and to allow a close assessment of the actual qualifications of recent arrivals. However, a careful review of the existing immigrant selection grid is also required to repair this job mismatch phenomenon. The selection grid must be revamped to put more emphasis on actual job placements prior to arrival since this would provide concrete evidence that Chinese education and experience actually match the Canadian qualifications for the intended occupation of the immigrant. 


\section{Appendix 1}

Some Characteristics of Chinese Immigrants by Year of Landing: 1980 - 1985

\begin{tabular}{|c|c|c|c|c|c|c|c|}
\hline \multirow{3}{*}{$\begin{aligned} & 1980-1985 \\
& \text { Total: } n=71349 \\
& \%=9.4 \%\end{aligned}$} & & \multicolumn{2}{|c|}{ Mainland China } & \multicolumn{2}{|c|}{ Hong Kong } & \multicolumn{2}{|c|}{ Taiwan } \\
\hline & & No. & $\%$ & No. & $\%$ & No. & $\%$ \\
\hline & & 41273 & 5.5 & 26720 & $3.5 \%$ & 3356 & $0.4 \%$ \\
\hline Top Five Receiving & Toronto & 11966 & 29 & 9691 & 36.3 & 1313 & 39.1 \\
\hline \multirow[t]{6}{*}{ Cities } & Vancouver & 10926 & 26.5 & 5715 & 21.4 & 853 & 25.4 \\
\hline & Montreal & 2490 & 6 & 1589 & 5.9 & 287 & 8.6 \\
\hline & Calgary & 2526 & 6.1 & 1971 & 7.4 & 154 & 4.6 \\
\hline & Edmonton & 2533 & 6.1 & 1818 & 6.8 & 136 & 4.1 \\
\hline & $1-19$ & 5838 & 14.1 & 10242 & 38.3 & 1170 & 34.9 \\
\hline & $20-39$ & 11463 & 27.8 & 13120 & 49.2 & 1441 & 42.9 \\
\hline \multirow[t]{2}{*}{ Age } & $40-59$ & 13113 & 31.8 & 2431 & 9.1 & 482 & 14.4 \\
\hline & $\geq 60$ & 10855 & 26.3 & 927 & 3.5 & 263 & 7.8 \\
\hline \multirow[t]{2}{*}{ Gender } & Male & 18736 & 45.4 & 13354 & 50 & 1448 & 43.1 \\
\hline & Female & 22536 & 54.6 & 13366 & 50 & 1908 & 56.9 \\
\hline \multirow[t]{5}{*}{ Marital Status } & Single & 11977 & 29 & 16813 & 62.9 & 1588 & 47.3 \\
\hline & Married & 23973 & 58.1 & 9405 & 35.2 & 1644 & 49 \\
\hline & Other & 5322 & 12.9 & 501 & 0.6 & 124 & 3.7 \\
\hline & Family & 22413 & 54.3 & 11913 & 44.6 & 1155 & 34.4 \\
\hline & Assisted Relative & 4695 & 11.4 & 2067 & 7.7 & 344 & 10.3 \\
\hline \multirow[t]{4}{*}{ Immigrant Class } & Other Independent & 1497 & 3.6 & 5007 & 18.7 & 642 & 19.1 \\
\hline & Entrepreneur & 1337 & 3.2 & 4358 & 16.3 & 672 & 20 \\
\hline & Investor & $\ldots$ & $\ldots$ & $\ldots$ & $\ldots$ & $\ldots$ & $\ldots$ \\
\hline & Retired & 1058 & 2.6 & 1262 & 4.7 & 129 & 3.8 \\
\hline \multirow[t]{3}{*}{ Level of Education } & 0 to 9 years & 26960 & 65.4 & 9469 & 35.5 & 1387 & 41.3 \\
\hline & 10 to 12 years & 6277 & 15.2 & 5252 & 19.7 & 522 & 15.6 \\
\hline & $\geq 13$ years & 8004 & 19.4 & 11989 & 44.9 & 1446 & 42.8 \\
\hline \multirow{2}{*}{$\begin{array}{l}\text { Canadian } \\
\text { Language Ability }\end{array}$} & English & 4490 & 10.9 & 13905 & 52.1 & 1281 & 36.3 \\
\hline & None & 36590 & 88.7 & 12682 & 47.5 & 2105 & 62.8 \\
\hline \multirow[t]{4}{*}{ Native Language } & Cantonese & 36372 & 88.1 & 24871 & 93.1 & 679 & 20.2 \\
\hline & Mandarin & 1697 & 4.1 & 245 & 0.9 & 2274 & 67.8 \\
\hline & Chinese & $\ldots$ & $\ldots$ & $\ldots$ & $\ldots$ & $\ldots$ & $\ldots$ \\
\hline & $\begin{array}{l}\text { Other Chinese } \\
\text { Dialects }\end{array}$ & 2477 & 6 & 671 & 2.5 & 297 & 8.9 \\
\hline
\end{tabular}

Source: Landed Immigrant Data System, 1980-2001

Note: ... Data is not available 


\section{Appendix 2}

Some Characteristics of Chinese Immigrants by Year of Landing: 1986 - 1990

\begin{tabular}{|c|c|c|c|c|c|c|c|}
\hline \multirow{2}{*}{$\begin{array}{c}\text { 1986-1990 } \\
\text { Total: } n=127681 \\
\%=16.9 \%\end{array}$} & & \multicolumn{2}{|c|}{ Mainland China } & \multicolumn{2}{|c|}{ Hong Kong } & \multicolumn{2}{|c|}{ Taiwan } \\
\hline & & No. & $\%$ & No. & $\%$ & No. & $\begin{array}{l}\% \\
14\end{array}$ \\
\hline Top Five & Toronto & 16084 & 38.2 & 38033 & 51 & 2922 & 26.9 \\
\hline \multirow[t]{6}{*}{ Receiving Cities } & Vancouver & 9731 & 23.1 & 16303 & 21.8 & 4325 & 39.8 \\
\hline & Montreal & 3370 & 8 & 5233 & 7 & 2573 & 23.9 \\
\hline & Calgary & 2165 & 5.1 & 3467 & 4.6 & 146 & 1.3 \\
\hline & Edmonton & 2126 & 5.1 & 3202 & 4.3 & 171 & 1.6 \\
\hline & $1-19$ & 2934 & 7 & 27880 & 37.3 & 4474 & 41.2 \\
\hline & $20-39$ & 15911 & 37.8 & 37719 & 50.5 & 4101 & 36.8 \\
\hline \multirow[t]{2}{*}{ Age } & $40-59$ & 14082 & 33.4 & 8092 & 10.8 & 2141 & 19.7 \\
\hline & $\geq 60$ & 9149 & 21.7 & 1049 & 1.4 & 246 & 2.3 \\
\hline \multirow[t]{2}{*}{ Gender } & Male & 20352 & 48.4 & 36388 & 48.7 & 5176 & 47.6 \\
\hline & Female & 21723 & 51.6 & 38351 & 51.3 & 5687 & 52.4 \\
\hline \multirow[t]{5}{*}{ Marital Status } & Single & 10663 & 25.3 & 43509 & 58.2 & 5845 & 53.8 \\
\hline & Married & 27415 & 65.2 & 30290 & 40.5 & 4871 & 44.8 \\
\hline & Other & 3987 & 9.5 & 928 & 1.2 & 146 & 1.3 \\
\hline & Family & 19590 & 46.6 & 9884 & 13.2 & 1003 & 9.2 \\
\hline & Assisted Relative & 3531 & 8.4 & 4403 & 5.9 & 298 & 2.7 \\
\hline \multirow[t]{4}{*}{ Immigrant Class } & Other Independent & 8319 & 19.8 & 24817 & 33.2 & 1278 & 11.8 \\
\hline & Entrepreneur & 4617 & 11 & 13415 & 17.9 & 4788 & 44.1 \\
\hline & Investor & 1136 & 2.7 & 2911 & 3.9 & 2283 & 21 \\
\hline & Retired & 2536 & 6 & 3481 & 4.7 & 713 & 6.6 \\
\hline Level of & 0 to 9 years & 18508 & 44 & 27899 & 37.3 & 4620 & 42.5 \\
\hline \multirow[t]{2}{*}{ Education } & 10 to 12 years & 7579 & 18 & 13771 & 18.4 & 1958 & 18 \\
\hline & $\geq 13$ years & 15990 & 38 & 33071 & 44.2 & 4285 & 39.4 \\
\hline Canadian & English & 13386 & 31.8 & 42699 & 57.2 & 3434 & 31.6 \\
\hline Language Ability & None & 28315 & 67.3 & 31611 & 42.3 & 7380 & 68 \\
\hline \multirow[t]{4}{*}{ Native Language } & Cantonese & 32946 & 78.3 & 72562 & 97.1 & 1320 & 12.2 \\
\hline & Mandarin & 5446 & 12.9 & 225 & 0.3 & 9176 & 84.5 \\
\hline & Chinese & 722 & 1.7 & 132 & 0.2 & 66 & 0.6 \\
\hline & $\begin{array}{l}\text { Other Chinese } \\
\text { Dialects }\end{array}$ & 2508 & 6 & 590 & 0.8 & 196 & 1.8 \\
\hline
\end{tabular}

Source: Landed Immigrant Data System, 1980-2001 


\section{Appendix 3}

Some Characteristics of Chinese Immigrants by Year of Landing: 1991 - 1995

\begin{tabular}{|c|c|c|c|c|c|c|c|}
\hline 1991 - 1995 & & Mainlaı & China & Hong $\mathrm{K}$ & ong & Taiwal & \\
\hline Total: $n=273297$ & & No. & $\%$ & No. & $\%$ & No. & $\%$ \\
\hline$\%=36.2 \%$ & & 107383 & 14.2 & 130768 & 17.3 & 35146 & $4.7 \%$ \\
\hline Top Five & Toronto & 42037 & 39.1 & 56746 & 43.4 & 6834 & 19.5 \\
\hline Receiving Cities & Vancouver & 28088 & 26.2 & 40464 & 31 & 21244 & 60.5 \\
\hline & Montreal & 9239 & 8.6 & 11943 & 9.1 & 3587 & 10.2 \\
\hline & Calgary & 4375 & 4.1 & 5592 & 4.3 & 970 & 2.8 \\
\hline & Edmonton & 3985 & 3.7 & 4963 & 3.8 & 314 & 0.9 \\
\hline & $1-19$ & 12203 & 11.4 & 41675 & 31.9 & 13682 & 38.9 \\
\hline & $20-39$ & 39875 & 37.1 & 58422 & 46.7 & 11452 & 32.6 \\
\hline Age & $40-59$ & 29611 & 27.6 & 22994 & 17.6 & 9190 & 26.2 \\
\hline & $\geq 60$ & 25694 & 23.9 & 4977 & 3.8 & 822 & 2.3 \\
\hline Gender & Male & 50140 & 46.7 & 63287 & 48.4 & 17122 & 48.7 \\
\hline & Female & 57234 & 53.3 & 67476 & 51.6 & 18024 & 51.3 \\
\hline Marital Status & Single & 29426 & 27.4 & 76017 & 58.1 & 18855 & 53.6 \\
\hline & Married & 68838 & 64.1 & 52331 & 40 & 15756 & 44.8 \\
\hline & Other & 9115 & 8.5 & 2420 & 1.9 & 535 & 1.5 \\
\hline & Family & 53939 & 50.2 & 28798 & 22 & 2522 & 7.2 \\
\hline & Assisted Relative & 7359 & 6.9 & 28606 & 21.9 & 1939 & 5.5 \\
\hline Immigrant Class & Other Independent & 21793 & 20.3 & 14450 & 11.1 & 3683 & 10.5 \\
\hline & Entrepreneur & 6672 & 6.2 & 22898 & 17.5 & 6854 & 19.5 \\
\hline & Investor & 5456 & 5.1 & 14846 & 11.4 & 16065 & 45.7 \\
\hline & Retired & 6843 & 6.4 & 12267 & 9.4 & 2531 & 7.2 \\
\hline Level of & 0 to 9 years & 49087 & 45.7 & 46488 & 35.5 & 13909 & 39.6 \\
\hline Education & 10 to 12 years & 22259 & 20.7 & 35863 & 27.4 & 7419 & 21.1 \\
\hline & $\geq 13$ years & 36037 & 33.6 & 48417 & 37 & 13818 & 39.3 \\
\hline Canadian & English & 36834 & 34.3 & 73703 & 56.4 & 10771 & 30.7 \\
\hline Language Ability & None & 68818 & 64.2 & 56636 & 43.3 & 24263 & 69.1 \\
\hline Native Language & Cantonese & 68320 & 63.7 & 123427 & 94.4 & 1389 & 4 \\
\hline & Mandarin & 25631 & 23.9 & 843 & 0.6 & 30723 & 87.5 \\
\hline & Chinese & 9358 & 8.7 & 3256 & 2.4 & 2039 & 5.8 \\
\hline & $\begin{array}{l}\text { Other Chinese } \\
\text { Dialects }\end{array}$ & 1887 & 1.8 & 413 & 0.3 & 438 & 1.2 \\
\hline
\end{tabular}

Source: Landed Immigrant Data System, 1980-2001 


\section{Appendix 4}

Some Characteristics of Chinese Immigrants by Year of Landing: 1996 - 2001

\begin{tabular}{|c|c|c|c|c|c|c|c|}
\hline \multicolumn{2}{|l|}{$1996-2001$} & \multicolumn{2}{|c|}{ Mainland China } & \multicolumn{2}{|c|}{ Hong Kong } & \multicolumn{2}{|c|}{ Taiwan } \\
\hline \multirow{2}{*}{\multicolumn{2}{|c|}{ Total: $\begin{aligned} n & =283371 \\
\% & =37.5 \%\end{aligned}$}} & No. & $\%$ & No. & $\%$ & No. & $\%$ \\
\hline & & 184668 & 24.4 & 54609 & 7.2 & 44094 & 5.8 \\
\hline \multirow{5}{*}{$\begin{array}{l}\text { Top Five } \\
\text { Receiving Cities }\end{array}$} & Toronto & 89320 & 48.4 & 24770 & 45.4 & 8435 & 19.1 \\
\hline & Vancouver & 48775 & 26.4 & 21030 & 38.5 & 29358 & 66.6 \\
\hline & Montreal & 13022 & 7.1 & 2903 & 5.3 & 3242 & 7.4 \\
\hline & Calgary & 5644 & 3.1 & 1847 & 3.4 & 1011 & 2.3 \\
\hline & Edmonton & 3355 & 1.8 & 1328 & 2.4 & 314 & 0.7 \\
\hline \multirow{4}{*}{ Age } & $1-19$ & 37863 & 20.5 & 18658 & 34.2 & 16724 & 37.9 \\
\hline & $20-39$ & 107397 & 58.2 & 23382 & 42.8 & 15533 & 35.3 \\
\hline & $40-59$ & 27162 & 14.7 & 11274 & 20.6 & 11259 & 25.5 \\
\hline & $\geq 60$ & 12244 & 6.6 & 1295 & 2.4 & 578 & 1.3 \\
\hline \multirow{2}{*}{ Gender } & Male & 88603 & 48 & 25549 & 46.8 & 21493 & 48.7 \\
\hline & Female & 96058 & 52 & 29060 & 53.2 & 22601 & 51.3 \\
\hline \multirow[t]{5}{*}{ Marital Status } & Single & 58394 & 31.6 & 27692 & 50.7 & 21557 & 48.9 \\
\hline & Married & 119855 & 64.9 & 25752 & 47.2 & 21868 & 49.6 \\
\hline & Other & 6384 & 3.5 & 1164 & 2.1 & 641 & 1.5 \\
\hline & Family & 39023 & 21.1 & 7874 & 14.4 & 2565 & 5.8 \\
\hline & Assisted Relative & 11923 & 6.5 & 19412 & 35.5 & 6847 & 15.5 \\
\hline \multirow[t]{4}{*}{ Immigrant Class } & Other Independent & 108108 & 58.5 & 12252 & 22.4 & 20008 & 45.4 \\
\hline & Entrepreneur & 5157 & 2.8 & 7615 & 13.9 & 5075 & 11.5 \\
\hline & Investor & 10215 & 5.5 & 5082 & 9.3 & 7064 & 16 \\
\hline & Retired & 57 & 0 & 89 & 0.2 & 47 & 0.1 \\
\hline \multirow{3}{*}{$\begin{array}{l}\text { Level of } \\
\text { Education }\end{array}$} & 0 to 9 years & 56996 & 30.9 & 19952 & 36.5 & 16060 & 36.4 \\
\hline & 10 to 12 years & 15877 & 8.6 & 13522 & 24.8 & 6480 & 14.7 \\
\hline & $\geq 13$ years & 111795 & 60.5 & 21135 & 38.7 & 21554 & 48.9 \\
\hline \multirow{2}{*}{$\begin{array}{l}\text { Canadian } \\
\text { Language Ability }\end{array}$} & English & 65319 & 35.4 & 30590 & 56 & 18519 & 42 \\
\hline & None & 118150 & 64 & 23861 & 43.7 & 25452 & 57.7 \\
\hline \multirow[t]{4}{*}{ Native Language } & Cantonese & 30450 & 16.5 & 47262 & 86.5 & 502 & 1.1 \\
\hline & Mandarin & 111756 & 60.5 & 678 & 1.2 & 37137 & 84.2 \\
\hline & Chinese & 41138 & 22.3 & 5012 & 9.2 & 6035 & 13.7 \\
\hline & $\begin{array}{l}\text { Other Chinese } \\
\text { Dialects }\end{array}$ & 121 & 0.1 & 5 & 0 & 18 & 0 \\
\hline
\end{tabular}

Source: Landed Immigrant Data System, 1980-2001 


\section{References}

Citizenship and Immigration Canada (1999). Report to SOPEMI on immigration to Canada. Ottawa: Citizenship and Immigration Canada.

Con, H., Con, R.J., Johnson, G., Wickberg, E., \& Willmott, W.E. (1982). From China to Canada: A history of the Chinese communities in Canada. Toronto: McClelland and Stewart Ltd.

Knowles, V. (1997). Strangers at our gates: Canadian immigration and immigration policy, 1540-1997. Toronto: Dundurn Press.

Kotkin, J. (1993). Tribes: How race, religion, and identity determine success in the global economy. New York: Random House.

Li, P.S. (2003). Destination Canada: Immigration debates and issues. Don Mills: Oxford University Press.

Li, P.S. (1998). The Chinese in Canada. Don Mills: Oxford University Press.

Matas, D. (1996). Racism in Canadian immigration policy. In C. E. James (Ed.), Perspectives on racism and the human services sector: A case for change (pp.93-102). Toronto: University of Toronto Press.

Pivnenko, S. \& DeVoretz, D. J. (2004). The recent economic performance of Ukrainian immigrants in Canada and the US. RIIM Working Paper Series No. 03-10; IZA Working Paper No. 913.

Statistics Canada (2003). 2001 census: Analysis series. Ottawa: Statistics Canada.

Shi, Y. (2004). The impact of Canada's new immigration act on Chinese independent immigrants. The Canadian Journal of Urban Research, 13 (1), 140-154.

Tan, J. \& Roy, P. E. (1985). The Chinese in Canada. Ottawa: Canadian Historical Association.

Tseng, Y.F. (2001). New patterns of Taiwanese emigration: Capital-linked migration and its importance for economic development. In C. Aspalter (Ed.), Understanding modern Taiwan: Essays in economics, politics and social policy. Aldershot, Hampshire: Ashgate.

Wallis, D. (1998). Beijing makes it happen. Vis-à-Vis, Fall, 1998, 4-8.

Whitaker, R. (1991). Canadian immigration policy since confederation. Ottawa: Canadian Historical Association.

Wong, S.L. (1992). Emigration and stability in Hong Kong. Hong Kong: the University of Hong Kong. 